servation of books, pamphlets, manuscripts, deeds, engravings, drawings, coins, antiquities, and any objects relating to the history of the country and its inhabitants, and the cataloguing of any such not in the possession of the Society; the transcription and publication of public records, registers, and other documents; the preservation of plans and views of buildings and other objects of interest; the publication of papers on subjects of historical and antiquarian interest to Kenya, and of biographical and genealogical notices of Kenya people; the collection of material for, and the publication of, a history of the country.

The Society intends to publish an annual Journal for distribution amongst its members, from whom it would welcome contributions.

Further particulars concerning the Society and membership (Shs. $30 /$-per year, or $£ 20$ for Life Membership) may be obtained from the Hon. Secretary, P.O. Box 4474, Westlands, Nairobi.

\title{
Regional Co-operation in British East Africa
}

THE East Africa High Commission, established in I948, was the culmination of over 20 years' effort to organize a means whereby many of the general problems of the East African territories could be tackled in common, without making any changes in the constitution or administrative responsibilities of the several territorial governments.

The history of co-operation between the three territories-Kenya, Uganda, and Tanganyika-goes back to 1917 with the establishment of a joint customs service for Kenya and Uganda; in 1920 the East African Currency Board was formed, and the currency common to Uganda and Kenya was extended to Tanganyika and Zanzibar. Further interterritorial co-operation was developed during the period $1924-3 \mathrm{I}$ and during the war, and by the end of 1944 the process of collaboration had resulted in the growth of a form of central administration for many subjects, including research and higher education. The general desire, after the war, to consolidate this machinery and provide a practicable means of dealing with common services, resulted, after much discussion and some controversy, in the establishment of the High Commission and Central Legislative Assembly in I948.

The work of the High Commission is perhaps most evident in the improvement and expansion of communications-railways, roads, harbours, air services, posts and telecommunications-but its research and scientific services are equally valuable. In agriculture, forestry and veterinary research, in tsetse and trypanosomiasis research, in the work of the locust survey and control service, the advantages of a concerted approach to problems of this kind is clear. Five services concerned with research in medicine and hygiene work under the aegis of the High Commission and have contributed substantially to the control of disease and the improvement of health throughout East Africa.

In the educational field the High Commission's chief contribution is provided by the East African Literature Bureau, set up in 1948 to organize the provision of books and magazines, chiefly for Africans, to assist African authors, and to establish libraries. The Bureau itself carries out publication, as well as publishing through private firms, and its publications are in Swahili, English, and a number of Kenya and Uganda vernacular languages; subjectmatter ranges from agriculture and civics to poetry and tribal lore. The Bureau's own Magazine Tazama has a weekly circulation among Africans of more than 12,000. Library services are expanding with the provision of more library centres, and postal library services are in operation in the three territories; the promotion of bookselling has recently been aided by the use of mobile units. 